\title{
Flutamide effects on morphology of reproductive organs and liver of Neotropical Anura, Rhinella schneideri
}

\author{
Lara S. de Gregorio ${ }^{a, *}$, Lilian Franco-Belussi ${ }^{\mathrm{b}}$, Fernando R. Gomes ${ }^{\mathrm{c}}$, Classius de Oliveira ${ }^{\mathrm{b}}$ \\ a Graduate Program in Animal Biology, UNESP-Universidade Estadual Paulista, Biology Department, Rua Cristóvão Colombo, 2265, Jardim Nazareth, \\ 15054-000 São José do Rio Preto (Ibilce), Brazil \\ b UNESP-Universidade Estadual Paulista, Biology Department, Rua Cristóvão Colombo, 2265, Jardim Nazareth, 15054-000 São José do Rio Preto (Ibilce), \\ Brazil \\ ' USP-Universidade de São Paulo, Instituto de Biociências, Physiology Department, São Paulo, Brazil
}

\section{A R T I C L E I N F O}

\section{Article history:}

Received 27 January 2016

Received in revised form 22 April 2016

Accepted 25 April 2016

Available online 27 April 2016

\section{Keywords:}

Endocrine disrupting

Testis

Bidder's organ

Hepatic pigmentation

Testosterone

Estradiol

Bufonidae

\begin{abstract}
A B S T R A C T
Water contamination is one of the factors influencing the decline of amphibians. Flutamide is an antiandrogenic medicine that occurs as water contaminant. This compound especially affects the reproductive organs, but it can also show hepatotoxic effects. The Bufonidae family has a peculiar organ named Bidder's organ, considered by some authors as a rudimentary ovary, but capable to respond to some external stimuli. This study investigated flutamide effects on testes and Bidder's organ germ cells, liver pigmentation, and sexual hormones levels in Rhinella schneideri males. We randomly divided 15 males in three groups $(N=5)$ : two groups were injected with flutamide, at 1 and $5 \mathrm{mg} / \mathrm{kg}$, while the control group received only mineral oil, for 7 days. After euthanasia, blood samples were collected and the organs were sent to histological routine. In the testes, both treatments caused an increase in spermatogonia and spermatocytes, and a decrease in spermatozoa and locular area. In the Bidder's organ, the final diplotene oocytes increased, but the initial diplotene, degrading and atresic oocytes reduced in both treatments. The lipofuscin in the Bidder's organ was not affected. In the liver, melanin and lipofuscin increased only for the $1 \mathrm{mg} / \mathrm{kg}$ flutamide treatment. The $5 \mathrm{mg} / \mathrm{kg}$ treatment did not affect the liver. Serum testosterone and estradiol levels did not vary compared with the control group. This compound has antiandrogenic activity, which can affect the spermatogenetic process. The decrease in degrading and atresic Bidderian oocytes indicated that flutamide could stimulate the organ, retarding the degradation processes. The increase in liver melanin, which has protective role, and lipofuscin, a sign of degradation, indicates that flutamide cause hepatotoxic effects. So we conclude that flutamide negatively affects the testes, especially by reducing the sperm area, and the liver, inducing cell degradation and producing protective responses. Furthermore, the compound encourages lower degradation rates of the Bidder's organ germ cells.
\end{abstract}

(C) 2016 Elsevier B.V. All rights reserved.

\section{Introduction}

The amphibian populations are in decline worldwide, and are relatively more threatened than other vertebrates (Stuart et al., 2004; May, 2010). The causes of the decline include factors such as human activities that cause environmental changes and pollution (Wake and Vredenburg, 2008). Amphibians are dependent on the aquatic environment (Linzey, 2001) so that contamination of water bodies is a major factor contributing to the decline of populations (Hayes et al., 2010).

\footnotetext{
* Corresponding author.

E-mail addresses: lsg-lara@hotmail.com, lsglara.lsg@gmail.com (L.S. de Gregorio).
}

A class of contaminants much studied these days is the endocrine disrupting compounds (EDCs). These substances are capable of interfering with the endocrine system of organisms, even at low concentrations, and may act on several endocrine pathways (Bila and Dezotti, 2007). According to Orton and Tyler (2015), the EDCs could potentially affect the hypothalamic-pituitary-gonadal axis, and one of the most common effects is the occurrence of intersexual individuals. The incidence of these animals has been increasing over the years (1930-2001) along with pollution (Reeder et al., 2005), which is a strong indication of the relationship between EDCs and amphibian decline. Also, intersexual gonads were observed in $20 \%$ of Physalaemus cuvieri individuals collected in parts of the Atlantic Forest that presented residues of endocrine disrupting pesticide (dieldrin) (Moresco et al., 2014), further strengthening this relationship. 


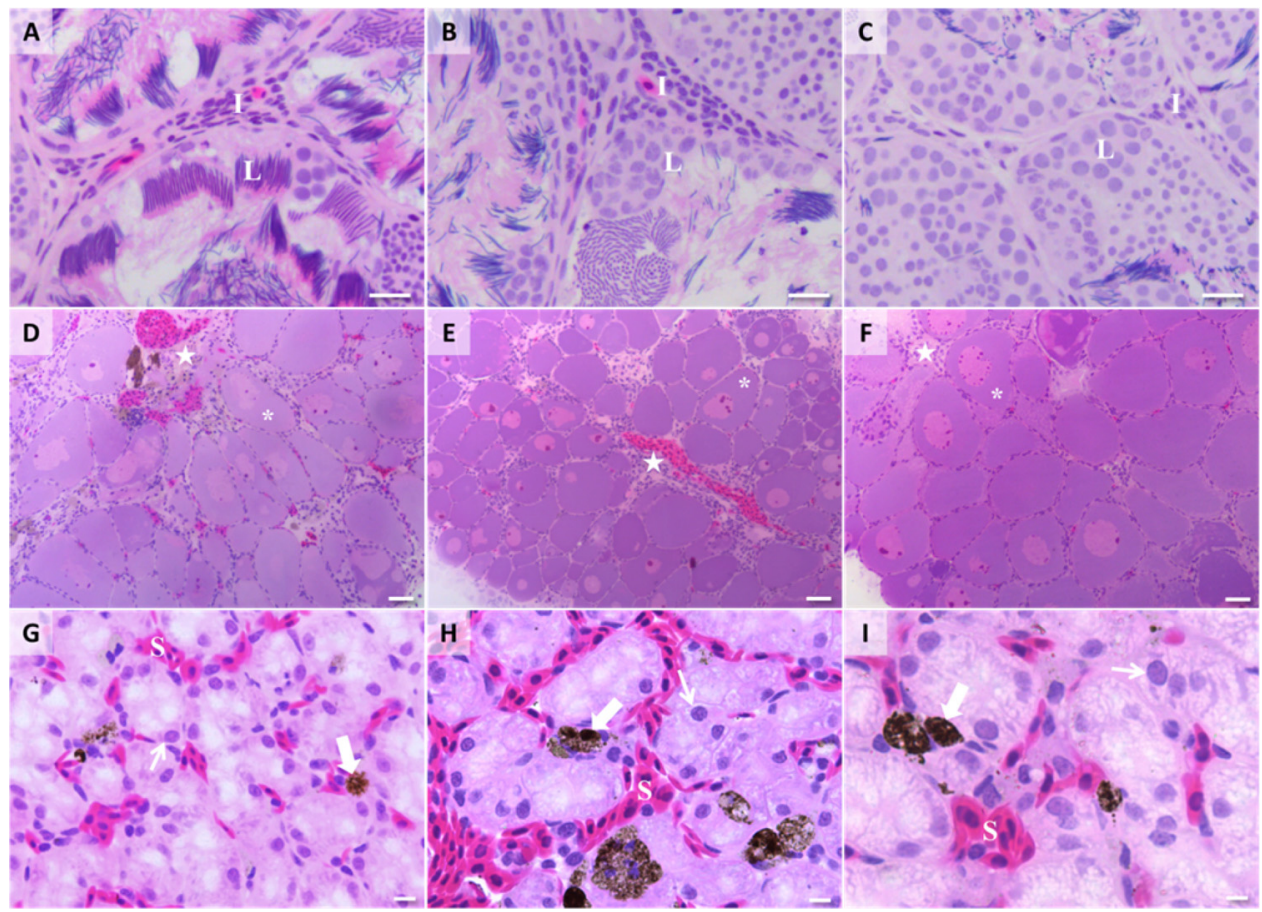

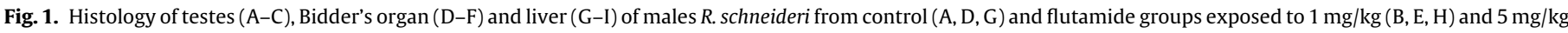

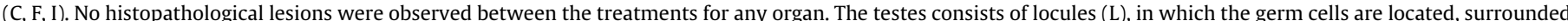

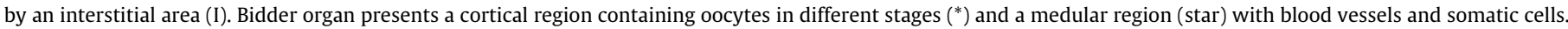


$25 \mu \mathrm{m}(\mathrm{A}-\mathrm{C}), 50 \mu \mathrm{m}$ (D-F) and $10 \mu \mathrm{m}(\mathrm{G}-\mathrm{I})$.

One of EDCs found in the aquatic environment is flutamide (IUPAC Name: 2-methyl- $N$-[4-nitro-3-(trifluoromethyl)phenyl]propanamide, CAS $\left.\mathrm{N}^{\circ}: 13311-84-7\right)$, a drug for prostate cancer that has anti-androgenic effect and competes for the androgen receptor (Pratt et al., 1994). Exposure to this contaminant affects mainly reproduction and can change the gonadal development (Kang et al., 2006) and the endocrine function of the gonads (Jensen et al., 2004) of fish. Furthermore, in amphibians, it has been observed to interfere with the expression of secondary sex characteristics like mate calling (Behrends et al., 2010) and nuptial pads, in addition to the serum testosterone levels (Van Wyk et al., 2003).

The Bufonidae family is distributed worldwide, except in Australia, where only an introduced species occurs (AmphibiaWeb, 2015). This family has the peculiar Bidder's organ, which is present in the anterior region of the gonad of both males and females (Pough et al., 2001) and produces female germ cells that degenerate (Duellman and Trueb, 1994). Some authors consider it a rudimentary ovary (Duellman and Trueb, 1994), but others claim that the organ can be functional (Farias et al., 2002). It has been observed that the germ cells show intense activity in males (Freitas et al., 2015) and respond to external stimuli (Pancak-Roessler and Norris, 1991; Brown et al., 2002). Furthermore, the presence of steroidogenic enzymes that convert male hormones into female hormones has been verified in various species (Colombo and Colombo-Belvedere, 1980; Gosh et al., 1982; Pancak-Roessler and Norris, 1991; Scaia et al., 2011), indicating that the body can respond to EDCs.

Although flutamide affects directly the reproductive organs, it can also affect other organs such as the liver, causing hepatotoxicity (Fau et al., 1994). This important organ is responsible for diverse metabolic functions, including the biotransformation of harmful agents (Saleh, 1982; Braunbeck et al., 1990; Fenoglio et al., 2005). In ectothermic animals, the liver can be affected by several biological and environmental factors, such as nutrition, pathogens, pollutants and environmental physicochemical factors (Bruslè and Anadon, 1996). Thus, the liver tissue is considered as a good biomarker for environmental impact studies (Stentiford et al., 2003).

Pigment cells with phagocytic activity are present in the hematopoietic organs of amphibians and other vertebrates. These cells are called melanomacrophages (Agius, 1980). Their main function is related with the phagocytosis of cellular material that originates from catabolism (Ellis et al., 1976), indicating that they play a role in the detoxification or recycling of endogenous and exogenous substances (Herráez and Zapata, 1986). The cytoplasm of melanomacrophages has different types of pigment granules, containing diverse compounds such as melanin and lipofuscin (Agius and Agbede, 1984; Herráez and Zapata, 1986). Melanin is synthesized endogenously (Césarini, 1996) and is related to the neutralization of free radicals, cations and other toxic compounds, originated from the degradation of the phagocytosed material (Zuasti et al., 1989; Agius and Roberts, 2003), and has bactericidal effect (Christiansen et al., 1996; Franco-Belussi et al., 2013). On the other hand, lipofuscin results from the oxidative polymerization of fatty acids, a process that involves reactive oxygen species (ROS), so that pigment production can be stimulated by the presence of these compounds (Terman and Brunk, 2004; Kurz, 2008).

Flutamide affects the endocrine pathways related to sex hormones. Therefore, we hypothesized that it can also change the morphology of the reproductive organs, plasma hormone levels, and stimulate liver responses due to liver metabolizing role and compound hepatotoxicity. Therefore, the objective was to assess whether flutamide could trigger (macro and microscopic) morphological changes in the reproductive organs of Rhinella schneideri (Werner, 1984), affecting Bidderian and testicular germ cells, and alter the serum levels of sex hormones and the hepatic pigmentation. 


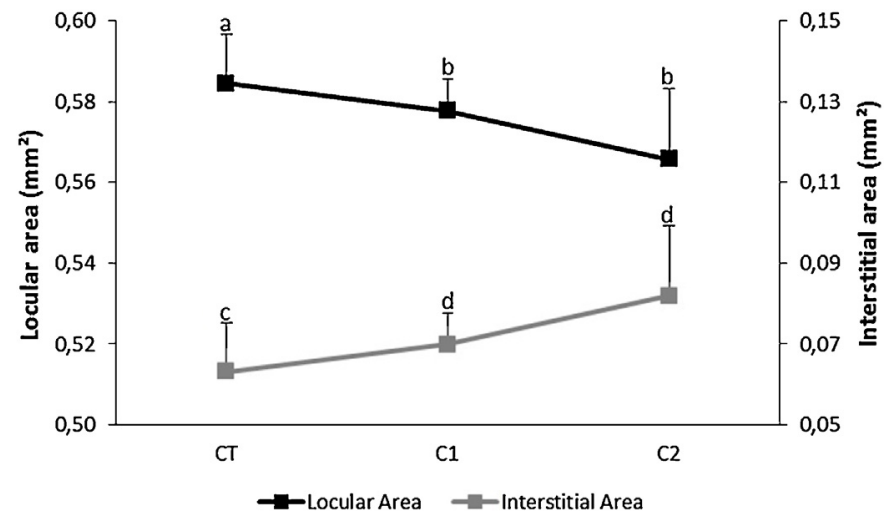

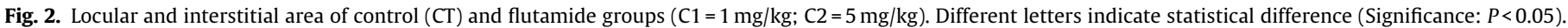
Mean \pm SEM. Statistical test: Kruskal-Wallis $(N=5 ; \mathrm{n}=125)$.

\section{Materials and methods}

We collected $15 R$. schneideri males between December 2013 and January 2014, in southeastern Brazil (2047_07.05_S; 49 02_42.09_W). During this period, the animals were kept at the Comparative Anatomy Laboratory (Ibilce - UNESP), at room temperature and natural photoperiod $\left(27 \pm 0.5^{\circ} \mathrm{C}\right.$ and $14 / 10 \mathrm{~h}$ light/dark). Seven days before the experiment began, the animals were put in the same terrariums used on the experiment, under the same conditions described above, for acclimation. We estimated the age of the animals between two and four years old, based on their snout-vent length (Arantes et al., 2015). All animals were collected during the mate calling to assure that they were adults. The experiment was approved by the Ethics Committee on Animal Use of Ibilce-UNESP (Protocol No. 098/2014), following the recommendations of the Guide for the Care and Use of Laboratory Animals (National Research Council (US) Committee).

\subsection{Experimental design}

The 15 animals were randomly divided in three groups $(N=5)$ and kept in terrariums of $73 \times 67 \times 42 \mathrm{~cm}$ (length $\times$ width $\times$ height) with approximately $5 \mathrm{~cm}$ of soil. They were fed with the black soldier fly (Hermetia illucens) three times a week and water was provided ad libitum. We had the control group and two groups exposed to flutamide at different concentrations. For seven days, the treated animals received daily subcutaneous injections with $0.2 \mathrm{~mL}$ of flutamide diluted in $100 \%$ mineral oil (Nujol ${ }^{\circledR}$ ) at concentrations of $1 \mathrm{mg} / \mathrm{kg}$ (C1) and $5 \mathrm{mg} / \mathrm{kg}$ (C2) per animal (5.4 and $18.1 \mathrm{mmol} / \mathrm{L}$, respectively). The animals in the control group (CT) received only mineral oil during the same period. After the experiment, the animals were euthanized in benzocaine anesthetic solution at $5 \mathrm{~g} / \mathrm{L}(30 \mathrm{mmol} / \mathrm{L})$. The blood was collected through cardiac puncture with heparinized syringes (Hemofol ${ }^{\circledR}$, diluted with water to $5000 \mu \mathrm{L} / \mathrm{mL}$ ) while the testicles, Bidder's organ, and liver were removed and sent to histological routine.

\subsection{Processing of the material}

The blood samples were immediately centrifuged at $603.72 \mathrm{~g}$ for $4 \mathrm{~min}$. The separated plasma was frozen in a freezer at $-80^{\circ} \mathrm{C}$ and used to determine testosterone and estradiol levels. The organs were fixed in Karnovsky solution (5\% paraformaldehyde and 2.5\% glutaraldehyde in $0.1 \mathrm{M}$ Sörensen phosphate buffer, $\mathrm{pH} 7.2$ ) for $24 \mathrm{~h}$. Subsequently, they were dehydrated in an alcoholic series and included in historesin (historesin Leica). A microtome (RM 2265, Leica) was used to prepare histological sections 3 micrometers thick. The histological sections of the testicle, Bidder's organ, and the liver were stained with hematoxylin-eosin to quantify germ cells and melanin. The Bidder's organ and liver were also stained with Schmorl solution for 15 min (1\% Ferric Chloride, 1\% Potassium ferricyanide and distilled water), counterstained with $1 \%$ Neutral Red and $1 \%$ Eosin to detect lipofuscin.

\subsection{Pathological analysis}

Following euthanasia, a visceral anatomical observation was performed to detect possible macroscopic abnormalities, before proceeding to the morphological analysis. The testes, Bidder's organ, and liver were weighed in an analytical precision scale $(0.001 \mathrm{~g})$, and subsequently submitted to histological routine for histopathological and morphometric analysis. Also, the viscerosomatic index of each organ was calculated by dividing the organ mass by the body mass.

\subsection{Morphometric and histopathological analysis}

The histological cuts of all organs were examined under a light microscope (Leica DM4000 B) to observe possible histopathological and structural changes in the tissues. After this, the organs underwent morphometric analysis to obtain quantitative data.

Twenty-five histological fields per animal were submitted to morphometric analyses using Image-Pro Plus v.6.0 (Media Cybernetics Inc., Silver Spring, MD, USA). In the testes, we measured the total locular area of each image (10× magnification), and the interstitial area was determined by subtracting the measured locular areas from the total area of the image, which was always entirely filled with testicular tissue to avoid overestimation. The areas occupied by the germ cells, such as spermatogonia, spermatocytes (primary + secondary), spermatids (primary + secondary) and spermatozoa (bundle + in the lumen), were also measured $(20 \times$ magnification).

In Bidder's organ, the germ cells (oocytes at initial and final diplotene, degenerating and in follicular atresia) were counted (10x magnification). Lipofuscin was measured by the color difference of the pigmented area. The same methodology was used to measure the liver area occupied by melanin and lipofuscin, at $20 \times$ magnification.

\subsection{Hormone analysis}

Plasma testosterone and estradiol levels were measured in duplicate, using ELISA assay kits (Cayman Chemical Company: Testosterone EIA Kit-item No. 582701; Estradiol EIA Kit-item No. 582 251). The plasma samples from each animal were previously thawed to perform the extraction procedure, according to Assis 

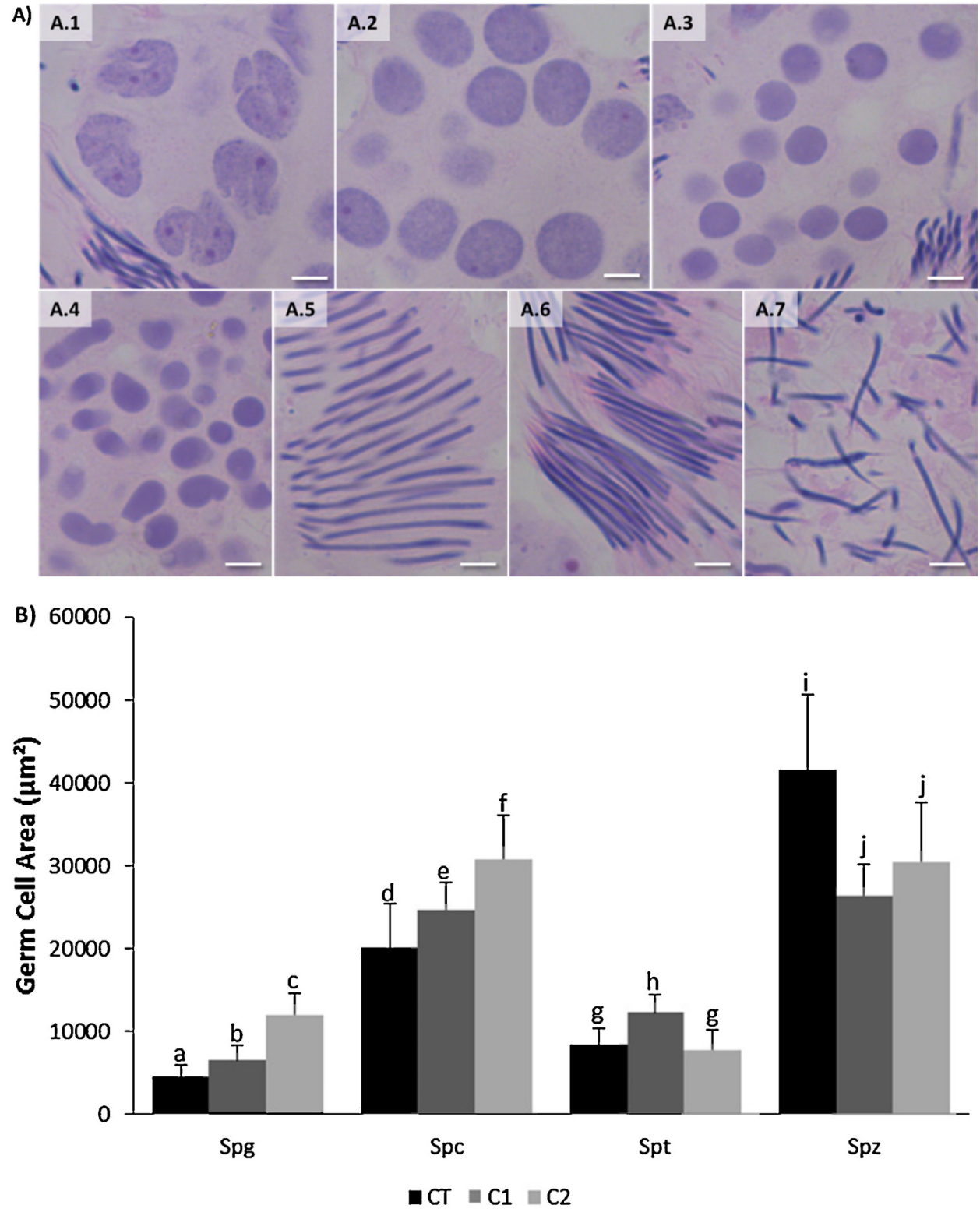

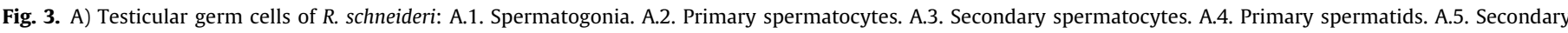

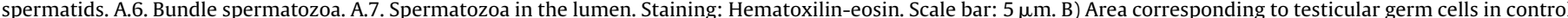

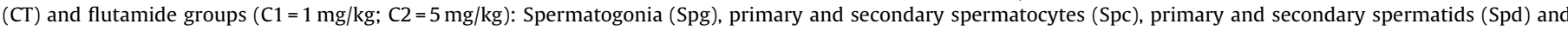

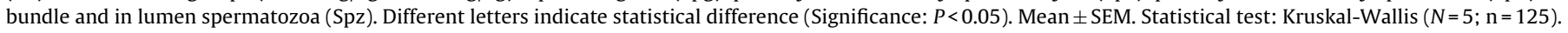

et al. (2015). Briefly, $3 \mathrm{~mL}$ of ether was added to $140 \mu \mathrm{L}$ of plasma; and the solution was vortexed for $30 \mathrm{~s}$ and then centrifuged for $9 \mathrm{~min}$ at $4{ }^{\circ} \mathrm{C}$ and $218 \mathrm{~g}$. Subsequently, the samples returned to the freezer at $-80^{\circ} \mathrm{C}$ for $7 \mathrm{~min}$ to decant, and the remaining liquid phase was transferred to another tube. After remaining at room temperature for $24 \mathrm{~h}$ for total volatilization of ether, the samples were re-suspended in EIA buffer and submitted to the hormone assays according to the manufacturer's instructions. The intra-assay variation, estimated from the duplicates of the samples, was $3.79 \%$ and $14.68 \%$ for testosterone and estradiol, respectively. The sensitivity of the assays was 32 and $129 \mathrm{pg} / \mathrm{mL}$ for testosterone and estradiol, respectively. All hormonal analyses were performed at the Laboratório de Comportamento e Fisiologia Evolutiva from the Instituto de Biociências of USP (São Paulo).

\subsection{Statistical analysis}

All the statistical tests were run with the values obtained for the samples ( $N=5$; viscero-somatic index and hormonal analysis) or subsamples ( $n=125$; morphometric analysis), and we tested normality and homogeneity with the Shapiro-Wilk and Bartlett tests, respectively. The parametric data (whether transformed with Log10 or not) were submitted to One-way ANOVA variance test and the non-parametric data were analyzed with Kruskal-Wallis, followed by the post-hoc test. For the Bidder organ the data was in percentage, so we used the $G$ test for statistical analysis. The Spearman correlation test was run between melanin and lipofuscin in the liver, using the counts of both pigmented areas $(n=125)$ for each treatment. The mean values and the standard error of mean shown in the charts were calculated based on the measurements obtained 

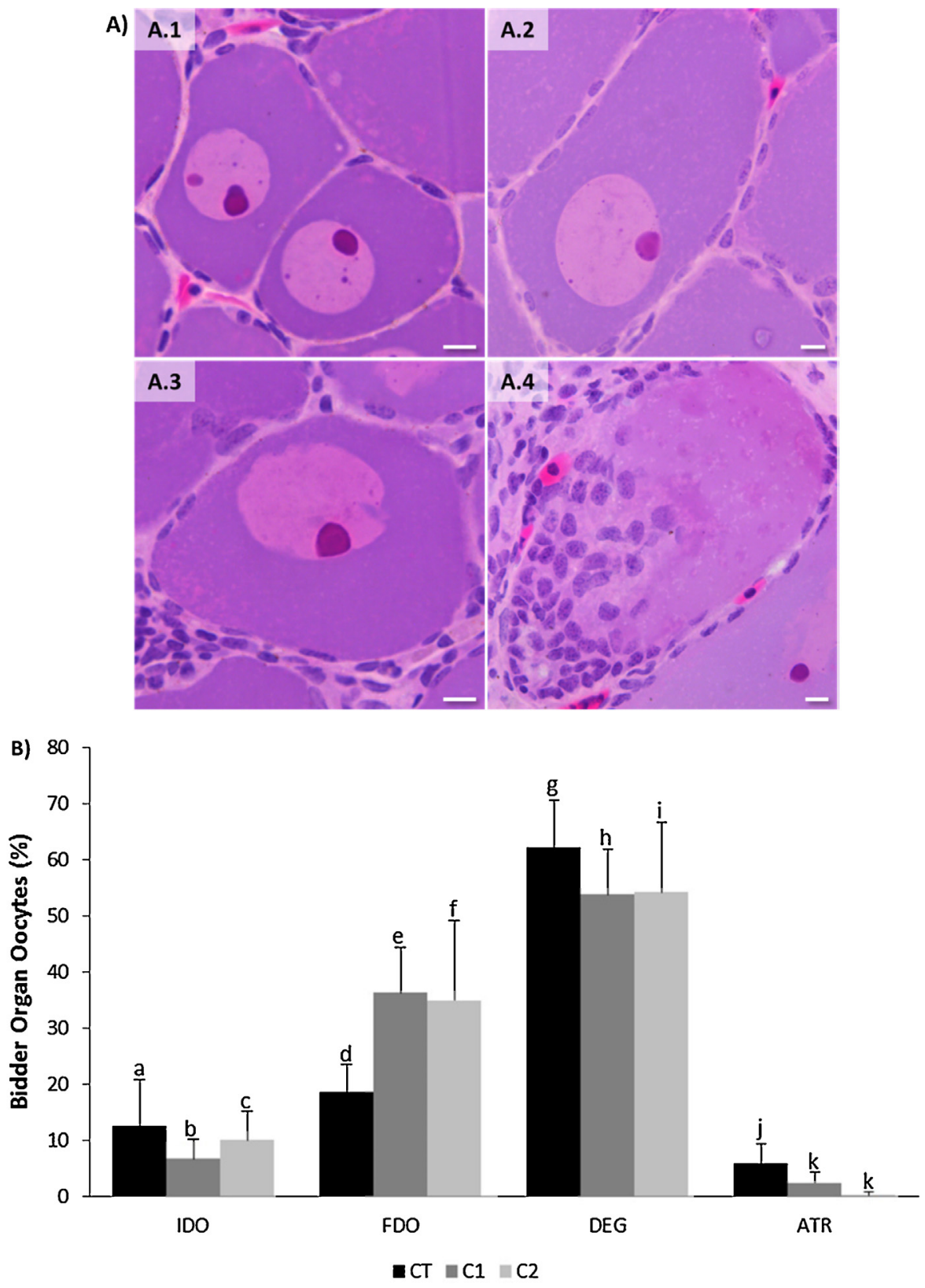

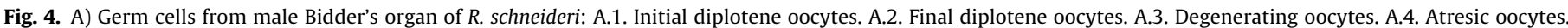

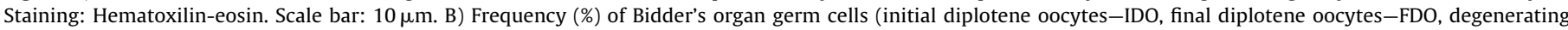

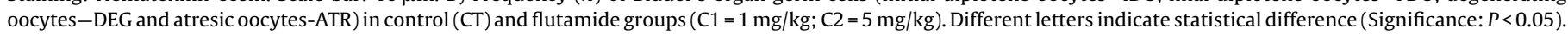
Mean \pm SEM. Statistical test: $G$ Test $(N=5 ; n=125)$.

for the samples or subsamples. The analysis were conducted using the $R$ version 2.11.1 software ( $R$ Development Core Team, 2010), with $P=0.05$ (Zar, 1999).

\section{Results}

The organs showed no clinical signs of anatomic abnormalities due to flutamide in either treatment. The viscero-somatic index did not vary for any organ (testes: $\mathrm{F}=2.997$ and $P=0.08$; Bidder's organ: $\mathrm{F}=0.305$ and $P=0.305$; liver: $\mathrm{F}=757$ and $P=0.49$ ) for both treatments. The general morphology of testes, Bidder's organ and liver (Fig. 1) showed no apparent histopathological lesions like vacuolization, fibrosis, hemorrhage, necrosis or neoplasia with the treatment.
In the control group, the total locular area represented $90 \%$ of the testicular tissue, while the interstitial region corresponded to $10 \%$. Both flutamide treatments reduced the locular area $\left(X^{2}=16.847\right.$; $P<0.01)$ and, consequently, the interstitial area increased proportionally $\left(X^{2}=16.612 ; P<0.01\right)$ (Fig. 2). The testicular germ cells (Fig. 3A) were also affected by flutamide (Fig. 3B). There was an increase in spermatogonia $\left(X^{2}=125.41\right.$ and $\left.P<0.01\right)$ and spermatocyte $\left(X^{2}=46.91\right.$ and $\left.P<0.01\right)$ areas while the spermatozoa area decreased $\left(X^{2}=48.83\right.$ and $\left.P<0.01\right)$ in both treatments. The spermatids increased only for the animals exposed to $1 \mathrm{mg} / \mathrm{kg}$ flutamide $\left(\mathrm{X}^{2}=48.03\right.$ and $\left.P<0.01\right)$.

Bidder's organ presents female germ cells at different stages of development (Fig. 4A), which usually degenerate. The treatment with flutamide at both concentrations showed the same results. There was an increase in the proportion of oocytes in final diplotene 

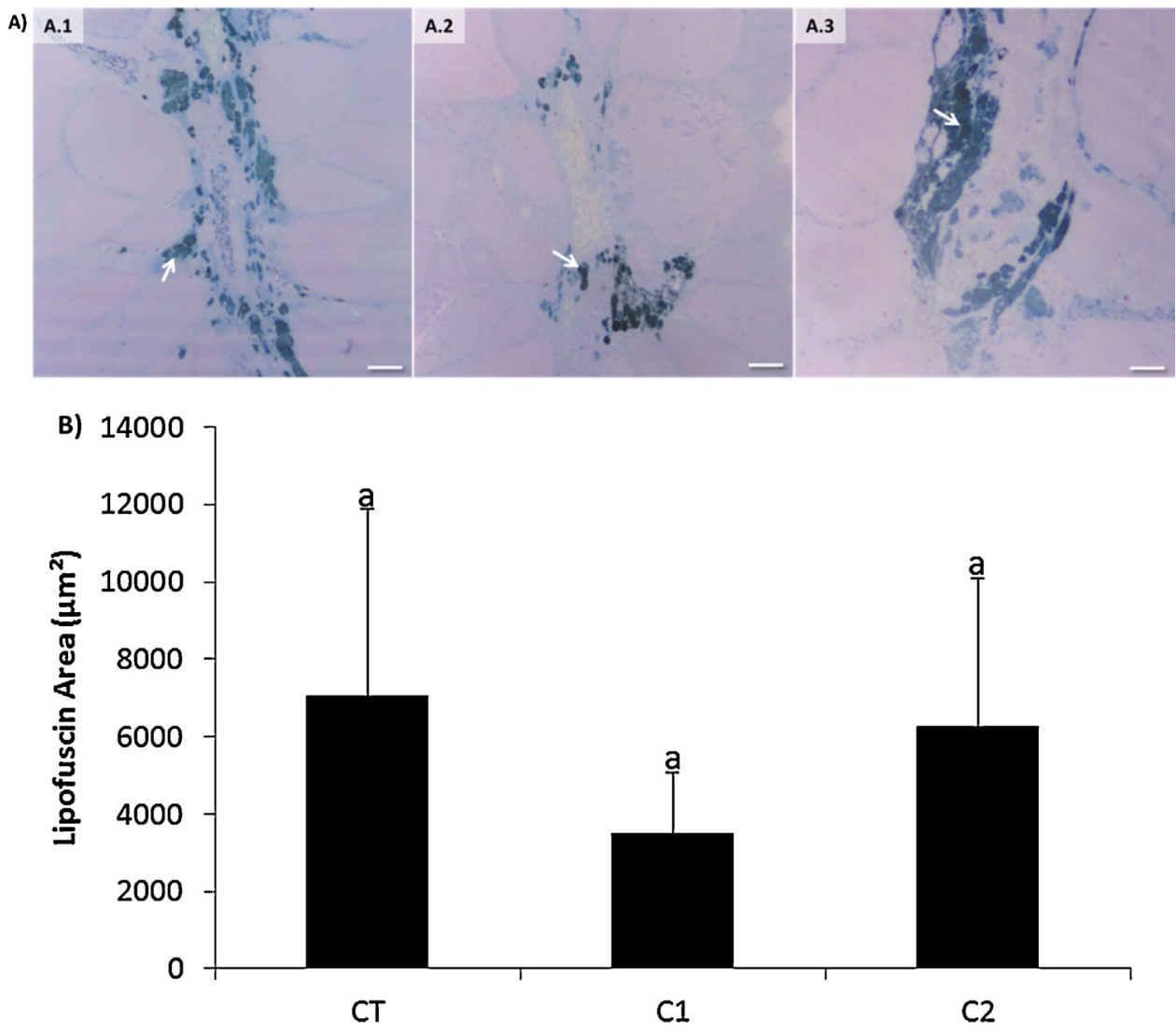

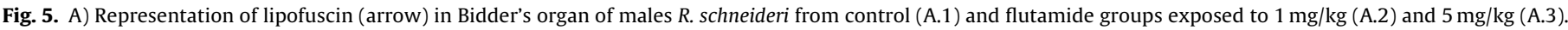

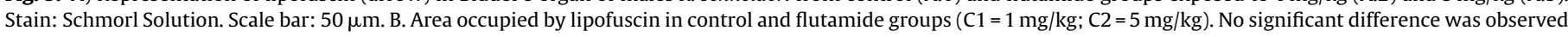
(Significance: $P<0.05)$. Mean \pm SEM. Statistical test: Kruskal-Wallis $(N=5 ; n=125)$.

stage $\left(\mathrm{G}_{\mathrm{CT}-\mathrm{C} 1}=1078.31 ; \mathrm{G}_{\mathrm{CT}-\mathrm{C} 2}=2563.84 ; \mathrm{G}_{\mathrm{C} 1-\mathrm{C} 2}=3441.66\right.$ and $P<0.01$ for all the comparisons), but the oocytes in initial diplotene $\left(\mathrm{G}_{\mathrm{CT}-\mathrm{C} 1}=2019.22 ; \mathrm{G}_{\mathrm{CT}-\mathrm{C} 2}=2862.73 ; \mathrm{G}_{\mathrm{C} 1-\mathrm{C} 2}=1380.86\right.$ and $P<0.01$ for all the comparisons), degenerating $\left(\mathrm{G}_{\mathrm{CT}-\mathrm{C} 1}=843.84\right.$; $\mathrm{G}_{\mathrm{CT}-\mathrm{C} 2}=1340.30 ; \mathrm{G}_{\mathrm{C} 1-\mathrm{C} 2}=2120.74$ and $P<0.01$ for all the comparisons) and in atresia $\left(\mathrm{G}_{\mathrm{CT}-\mathrm{C} 1}=733.32\right.$ and $P<0.01 ; \mathrm{G}_{\mathrm{CT}-\mathrm{C} 2}=189.44$ and $P<0.01 ; \mathrm{G}_{\mathrm{C} 1-\mathrm{C} 2}=128.99$ and $P=0.36$ ) decreased. The lipofuscin area (Fig. 5A) in Bidder's organ was not affected by flutamide at any studied concentration $\left(X^{2}=0.10\right.$ and $\left.P=0.95\right)$ (Fig. 5B).

In the liver, the pigmented areas of melanin and lipofuscin (Fig. 6A) were increased by flutamide at $1 \mathrm{mg} / \mathrm{kg}$, but not at $5 \mathrm{mg} / \mathrm{kg}$ (melanin: $X^{2}=45.56$ and $P<0.01$; lipofuscin: $X^{2}=73.39$ and $P<0.01$ ) (Fig. 6B). Furthermore, there was a positive correlation between the pigmented areas of melanin and lipofuscin in all the treatments (CT: $\rho=0.47$ and $P<0.01 ; \mathrm{C} 1: \rho=0.47$ and $P<0.01$; C2: $\rho=0.62$ and $P<0.01)$.

Plasma levels of testosterone and estradiol were not affected by flutamide at either concentrations (testosterone: $F=1.52$ and $P=0.26$; estradiol: $\mathrm{F}=0.17$ and $P=0.84$ ) (Fig. 7).

\section{Discussion}

Flutamide caused changes in male and female germ cells of $R$. schneideri. The observed changes in the testicles, especially the reduced spermatozoa area, can compromise the reproduction of these animals. The germ cells of Bidder's organ also responded to treatment, indicating that although some studies call it vestigial, the organ can become active. Furthermore, flutamide increased the area occupied by the melano-macrophagic pigment in the liver.

Both treatments affected the testicular germ cells, especially increasing the initial germ cells and reducing the spermatozoa areas. In addition, the locular area decreased while the interstitial increased. Flutamide competes for androgen receptors, inhibiting the intracellular action of these hormones (Pratt et al., 1994). The failure to capture testosterone can affect sperm production since the spermatogenetic process is dependent on these hormones (Junqueira and Carneiro, 2004). Flutamide also inhibits the negative feedback of testosterone, stimulating the release of FSH and LH (Viguier-Martinez et al., 1983). The rising FSH levels, in turn, may stimulate proliferation of germ cells in early stages (ViguierMartinez et al., 1983). Additionally, the high LH levels induces hypertrophy and hyperplasia of interstitial cells, and among them, the Leydig cells (Viguier-Martinez et al., 1983), which can lead to the effects observed in the interstitial area. The flutamide action on hormonal pathways may have led to the responses observed in this study, since the initial cell types were stimulated while the spermatozoa, the final stage of spermatogenesis, reduced.

There are other studies in the literature reporting that flutamide may impair reproductive aspects of other animals. Fish exposed to this compound for long periods had reduced quality and quantity of sperm, besides the occurrence of intersex gonads (Jensen et al., 2004; Kang et al., 2006). The sperm count is also affected in rats exposed to flutamide (Anway et al., 2008; Leonelli et al., 2011). In the literature, there are no studies with amphibians evaluating the direct effect of flutamide on germ cells. However, it has been observed that secondary sexual characteristics like the mate call (Behrends et al., 2010) and the nuptial pads (Van Wyk et al., 2003) are negatively affected while also interfering with general reproduction.

In Bidder's organ, both treated groups showed an increase in final diplotene oocytes, while the initial diplotene, degrading and atresic oocytes decreased. There are no studies evaluating the 

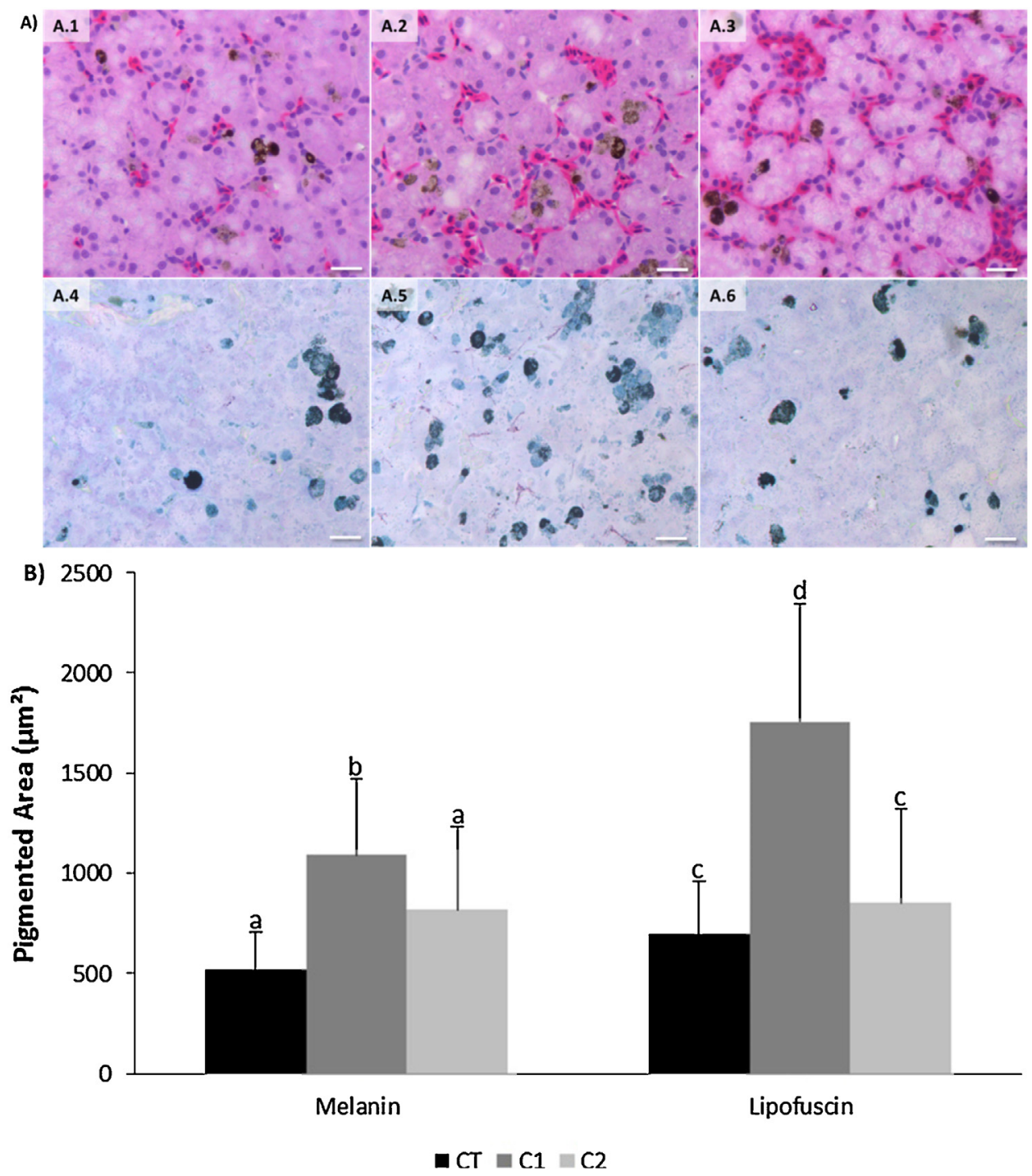

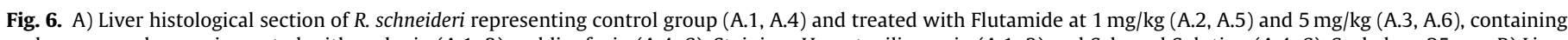

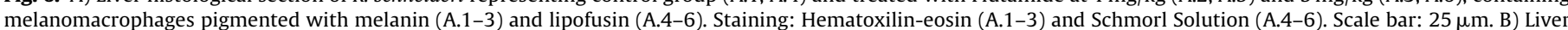

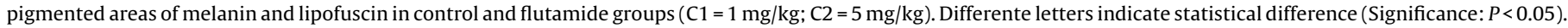
Mean \pm SEM. Statistical test: Kruskal-Wallis $(N=5 ; n=125)$.

effects of anti-androgens in adult Bidder's organ. It is well known that flutamide competes for androgen receptors, what could lead to an increase in serum testosterone levels (Pratt et al., 1994). Also, several species of the Bufonidae family have steroidogenic enzymes in this organ that are able to convert androgens to estrogens (Colombo and Colombo-Belvedere, 1980; Gosh et al., 1982; Pancak-Roessler and Norris, 1991; Scaia et al., 2011). Thus, these enzymes could have been stimulated by the higher levels of serum testosterone, producing estrogenic hormones that stimulate the development of the oocytes and lowers degradation rates. We also investigated the lipofuscin pigmented area, which was not affected by flutamide. This pigment is generated as a by-product of membrane degradation (Terman and Brunk, 2004), so we expected that less degrading and atresic oocytes would result for less lipofuscin. However, this was not observed, but the very high standard deviation could have interfered at the statistical results.

In the liver, the lipofuscin and melanin pigmented areas increased with exposure to flutamide at $1 \mathrm{mg} / \mathrm{kg}$ and were positively correlated. Some studies showed that flutamide is oxidatively transformed into reactive metabolites by cytochrome P450 (CYP) (Berson et al., 1993), a process that can lead to oxidative stress by the stimulation of some CYP enzymes, mitochondrial superoxides, and lipid peroxidation (Berson et al., 1993; Kashimshetty et al., 2009; Shimamoto et al., 2011). The process of lipid peroxidation culminates in free radicals production (Shimamoto et al., 2011), which can be neutralized by melanin (Zuasti et al., 1989; Agius and Roberts, 2003) and results in lipofuscin production, among other substances (Agius and Roberts, 2003). This could explain the increase in melanin and lipofuscin, as well as the positive correlation between the pigments since it is possibly a common factor influencing both pigments. There are other factors that affect melanin and lipofuscin, so it is understandable that the correlation was moderate. These pigments can also respond to pathogenic compounds like bacterial lipopolysaccharides and other pollutants like the herbicide glyphosate, even in a short exposure time ( $48 \mathrm{~h}$ ) (Franco-Belussi et al., 2013; Pérez-Iglesias et al., 2016), so we believe that they could be good biomarkers of hepatotoxicity.

Plasma levels of testosterone and estradiol did not vary between the control and treated groups. Usually, serum hormone levels are highly variable, especially in individuals from wild populations. Also, the exposure time to flutamide may have been too short to generate meaningful responses of hormone levels. Other studies 


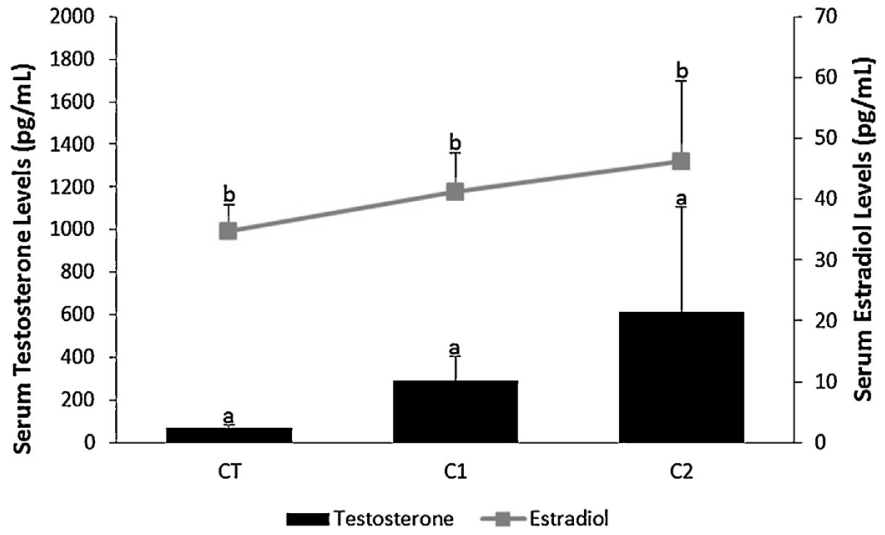

Fig. 7. Serum testosterone and estradiol levels in males $R$. schneideri from control and flutamide groups $(\mathrm{C} 1=1 \mathrm{mg} / \mathrm{kg} ; \mathrm{C} 2=5 \mathrm{mg} / \mathrm{kg})$. No statistical difference was observed (Significance: $P<0.05$ ). Média + SEM. Statistical test: One-way ANOVA $(N=5)$.

with reptiles and amphibians show that exposure to flutamide increased testosterone, possibly due to competition for androgen receptors and inhibition of the negative feedback mechanism (Tokarz, 1987; Van Wyk et al., 2003). In addition, we observed morphological changes on both reproductive organs that are dependent on hormones. Welshons et al. (2003) stated that even a small hormonal change due to EDC exposure can affect the organism and thus, although not statistically significant, hormonal variation may have been enough to change the morphology of testes and Bidder's organ.

In our study we could see that flutamide shows no doseresponse effect pattern. Nevertheless, the reproductive organs showed similar responses to both concentrations in almost all analysis, probably due to flutamide action mode, that interferes directly with sexual aspects. In the liver, the higher concentration had no effects. EDCs commonly respond better in low-doses and there are some studies assessing exactly why this happens. Some authors hypothesized that compounds that interact with hormone receptors should act in very low doses, just like the endogenous hormones (Welshons et al., 2003; Vandenberg et al., 2012). Also, the relationship between the substance concentration and the number of bound receptors, and between bound receptors and the response are nonlinear (Vandenberg et al., 2012). It means that, in low-dose exposures, even if the receptors are not saturated, the maximum response can be observed, while in higher doses exposures, when the receptors are saturated, the response to this saturation can comes first (Welshons et al., 2003). Thus, the non-response of the liver to the higher concentration is probably associated with flutamide toxicodynamics, and could not be predicted based on different concentrations.

Both doses used in this study seem to be high compared with other studies with EDCs, but there is only one study that quantified the environmental concentrations of flutamide, and it ranges from 0.35 to $5.1 \mathrm{mg} / \mathrm{L}$ in Swedish landfill leachates (Sjöholm, 2005). In Brazil it is very common to dump sewage effluents into rivers without any treatment, so we believe that these concentrations, although high, can very well exist at some contaminated sites of the country and can be harmful for the amphibians' conservation.

\section{Conclusion}

This study shows that aspects of amphibians' reproductive and metabolic physiology may be affected by flutamide. Therefore, it is important to study further the actual levels of this substance in the environment, in order to evaluate more accurately the potential risk to which these populations are subjected. We do not postulate mea- sures against the use of this drug. However, it is important to show evidence that the release of untreated sewage effluent can contaminate the aquatic environment and, therefore, affect the health and survival of native species.

With this study we concluded that flutamide affects the testicular germinal epithelium, especially by reducing spermatozoa and the locular area, stimulates the Bidder's organ oocytes and slows down cellular degradation. The reaction of the Bidder's organ to the compound indicates functionality. However, is not clear yet which roles Bidder's organ plays in animals of the family Bufonidae, so further investigative studies should be pursued. In the liver, the lower dose of flutamide increased the area occupied by melanin and lipofuscin pigments, indicating hepatotoxic effects.

\section{Conflict of interest}

The authors declare no competing or financial interests.

\section{Financial support}

This work was funded by Coordenação de Aperfeiçoamento de Pessoal de Nível Superior (CAPES/DS), Fundação de Amparo à Pesquisa do Estado de São Paulo (FAPESP) (\#2011/018407; \#2013/02067-5) and Conselho Nacional de Desenvolvimento Científico e Tecnológico (CNPq) (\#306123/2012-6). Lilian FrancoBelussi received post-doctoral scolarship (FAPESP \#2014/00946-4).

\section{Acknowledgments}

The authors are thankful to the technician Eduardo B. Fernandes for helping with the hormonal analysis and to the student Victor $\mathrm{M}$. Sacchi for his assistance in the collection and maintenance of the animals, and development of the experiment. Thanks to IBAMA for granting the license to collect the animals(18573-1).

\section{References}

Agius, C., Agbede, S.A., 1984. An electron microscopical study on the genesis of lipofuscin, melanin and haemosiderin in the haemopoietic tissues of fish. J. Fish Biol. 24 (4), 471-488.

Agius, C., Roberts, R., 2003. Melano-macrophage centres and their role in fish pathology. J. Fish Dis. 26, 499-509.

Agius, C., 1980. Phylogenetic development of Melano-Macrophage centers in fish. J. Zool. 191, 11-31.

AmphibiaWeb: Information on amphibian biology and conservation, 2015. Berkeley, California: AmphibiaWeb, Disponível em: <http://amphibiaweb.org/ lists/Bufonidae.shtml> (accessed 04.09.15).

Anway, M.D., Rekow, S.S., Skinner, M., 2008. Comparative anti-androgenic actions of vinclozolin and Flutamide on transgenerational adult onset desease and spermatogenesis. Reprod. Toxicol. 26, 100-106.

Arantes, I.C., Vasconcellos, M.M., Boas, T.C.V., Veludo, L.B.A., Colli, G.R., 2015. Sexual dimorphism, growth, and longevity of two toad species (Anura, Bufonidae) in a Neotropical Savanna. Copeia 103 (2), 329-342.

Assis, V.R., Titon, S.C.M., Barsotti, A.M.G., Titon Jr., B., Gomes, F.R., 2015. Effects of acute restraint stress, prolonged captivity stress and transdermal

corticosterone application on immunocompetence and plasma levels of corticosterone on the Cururu toad (Rhinella icterica). PLoS One 10, 1-21.

Behrends, T., Urbatzka, R., Krackow, S., Elepfandt, A., Kloas, W., 2010. Mate calling behavior of male South African clawed frogs (Xenopus laevis) is suppressed by the antiandrogenic endocrine disrupting compound flutamide. Gen. Comp. Endocrinol. 168, 269-274.

Berson, A., Wolf, C., Chachaty, C., Fisch, C., Fau, D., Eugene, D., Loeper, J., Gauthier, J. Beaune, P., Pompon, D., Maurel, P., Pessayre, D., 1993. Metabolic activation of the nitroaromatic antiandrogen flutamide by rat and human cytochromes $\mathrm{P}-450$ including forms belonging to the $3 \mathrm{~A}$ and $1 \mathrm{~A}$ subfamilies. J. Pharmacol. Exp. Ther. 265 (1), 366-372.

Bila, D.M., Dezotti, M., 2007. Desreguladores endócrinos no meio ambiente: efeitos e conseqüências. Quím. Nova 30 (3), 651-666.

Braunbeck, J.B., Storch, V., Bresch, H., 1990. Species-specific reaction of liver ultraestructure in zebrafish (Brachydanio rerio) and trout (Salmo gairdneri) after prolonged exposure to 4-chloroamine. Arch. Eviron. Contam. Toxicol. 19, 405-418 
Brown, F.D., del Pino, E.M., Krohne, G., 2002. Bidder's organ in the toad Bufo marinus: effects of orchidectomy on the morphology and expression of lamina-associated polypeptide 2. Dev. Growth Differ. 44 (6), 527-535.

Bruslè, J., Anadon, G.G., 1996. The structure and function of fish liver, pp. 77-93. In: Munshi, J.S.D., Dutta, H.M. (Eds.), Fish Morphology. Horizon of New Research, $1^{\mathrm{a}}$ ed. Science Publishers, Lebanon, 300p.

Césarini, J.P., 1996. Melanins and their possible roles through biological evolution. Adv. Space Res. 18 (12), 35-40.

Christiansen, J.L., Grzybowski, J.M., Kodama, R.M., 1996. Melanomacrophage aggregations and their age relationships in the yellow mud turtle Kinosternon flavescens (Kinosternidae). Pigment Cell Res. 9 (4), 185-190.

Colombo, L., Colombo-Belvedere, P., 1980. Steroid hormone biosynthesis by male Bidder's organ of the toad Bufo. Gen. Comp. Endocrinol. 40, 320-321.

Duellman, W.E., Trueb, L., 1994. Biology of Amphibians. McGgraw-hill, New York, $670 p$

Ellis, A.E., Munro, A.L.S., Roberts, R.J., 1976. Defense mechanism in fish: fate of intraperitoneally introduced carbon in the plaice (Pleuronectes platessa). J. Fish Biol. 8, 67-78.

Farias, C.F., Carvalho-e-Silva, S.P., Brito-Gitirana, L., 2002. Bidder's organ of Bufo ictericus: a light and electron microscopy analysis. Micron 33, 673-679.

Fau, D., Eugene, D., Berson, A., Letteron, P., Fromenty, B., Fisch, C., Pessayre, D. 1994. Toxicity of the antiandrogen Flutamide in isolated rat hepatocytes. J. Pharmacol. Exp. Ther. 269 (3), 954-962.

Fenoglio, C., Boncompagni, E., Fasola, M., Gandini, C., Comizzoli, S., Milanesi, G., Barni, S., 2005. Effects of environmental pollution on the liver. Ecotoxicol. Environ. Saf. 60 (3), 259-268.

Franco-Belussi, L., Castrucci, A.M.L., Oliveira, C., 2013. Responses of melanocytes and melanomacrophages of Eupemphix nattereri (Anura: leiuperidae) to Nle4 D-Phe7-alfa-melanocyte stimulating hormone and lipopolysaccharides. Zoology 116 (5), 316-324.

Freitas, J.S., Franco-Belussi, L., Oliveira, C., 2015. Morphological and histochemical studies of Bidder's organ in Rhinella schneideri (Amphibia: anura) males. Ital. J. Zool., 1-10

Gosh, P.K., Gosh, A.K., Biswas, N.M., 1982. Effect of cadmium chloride on steroidogenic enzymes in the Bidder's organ of the toad (Bufo melanosticus). Experientia 40, 91-92.

Hayes, T.B., Falso, P., Gallipeau, S., Stice, M., 2010. The cause of global amphibian declines: a developmental endocrinologist's perspective. J. Exp. Biol. 213, 921-933.

Herráez, M.P., Zapata, A.G., 1986. Structure and function of the melano-Macrophage centres of the goldfish Carassius auratus. Vet. Immunol. Immunopathol. 12, 117-126.

Jensen, K.M., Kahl, M.D., Makynen, E.A., Korte, J.J., Leino, R.L., Butterworth, B.C. Ankley, G.T., 2004. Characterization of responses to the antiandrogen flutamide in a short-term reproduction assay with the fathead minnow. Aquat. Toxicol. 70, 99-110.

Junqueira, L.C., Carneiro, J., 2004. Histologia Básica, 10ª ed. Guanabara Koogan, Rio de Janeiro, 488p

Kang, I.J., Hano, T., Oshima, Y., Yokota, H., Tsuruda, R., Shimasaki, Y., Honjo, T., 2006. Antiandrogen flutamide affects gonadal development and reproduction in medaka (Oryzias latipes). Mar. Environ. Res. 62, S253-S257.

Kashimshetty, R., Desai, V.G., Kale, V.M., Lee, T., Moland, C.L., Branham, W.S., New, L.S., Chan, E.C.Y., Younis, H., Boelsterli, U.A., 2009. Underlying mitochondrial dysfunction triggers flutamide-induced oxidative liver injury in a mouse model of idiosyncratic drug toxicity. Toxicol. Appl. Pharmacol. 238, 150-159.

Kurz, T., 2008. Can lipofuscin accumulation be prevented? Rejuvenation Res. 11 (2), 441-443.

Leonelli, C., Garcia, P.C., Pereira, O.C.M., 2011. Copulatory efficiency and fertility in male rats exposed perinatally to flutamide. Reprod. Toxicol. 31, 10-16.

Linzey, D., 2001. Vertebrate Biology, $1^{\text {a }}$ ed. McGraw-Hill, New York, 596p.

May, R.M., 2010. Ecological science and tomorrow's world. Philos. Trans. R. Soc. B $365,41-47$.

Moresco, R.M., Margarido, V.P., Oliveira, C., 2014. A persistent organic pollutant related with unusual high frequency of hermaphroditism in the neotropical anuran Physalaemus cuvieri Fitzinger, 1862. Environ. Res. 132, 6-11.
Orton, F., Tyler, C.R., 2015. Do hormone-modulating chemicals impact on reproduction and development of wild amphibians? Biol. Rev. 90, 1100-1117.

Pérez-Iglesias, J.M., Franco-Belussi, L., Moreno, L., Tripole, S., Oliveira, C., Natale, G.S., 2016. Effects of glyphosate on hepatic tissue evaluating melanomacrophages and erythrocytes responses in neotropical anuran Leptodactylus latinasus. Environ. Sci. Pollut. Res., http://dx.doi.org/10.1007/ 2016s11356-016061530z.

Pancak-Roessler, M.K., Norris, D.O., 1991. The effects of orchidectomy and gonadotropins in steroidogenesis and oogenesis in Bidder's organs of the toad Bufo woodhousii. J. Exp. Zool. 260, 323-336.

Pough, H.F., Andrews, R.M., Cadle, J.E., Crump, M.L., Savitzky, A.H., Wells, K.D., 2001. Herpetology, $2^{a}$ ed. Prentice-Hall, New Jersey, 612p.

Pratt, W.B., Ruddon, R.W., Ensminger, W.D., Maybaum, J., 1994. The Anticancer Drugs, $2^{a}$ ed. Oxford University Press, Nova York, 352p.

Reeder, A.L., Ruiz, M.O., Pessier, A., Brown, L.E., Levengood, J.M., Phillips, C.A., Wheeler, M.B., Warner, R.E., Beasley, V.R., 2005. Intersexuality and the Cricket Frog decline: historic and geographic trends. Environ. Health Perspect. 113 (3), 261-265.

Saleh, H.H., 1982. Fish liver as indicator of aquatic environmental pollution. Bull. Natl. Inst. Oceanogr. Fish. 8, 69-79.

Scaia, M.F., Regueira, E., Sassone, A.G., Volonteri, M.C., Ceballos, N.R., 2011. The Bidder's organ of the toad Rhinella arenarum (Amphibia, Anura). Presence of steroidogenic enzymes. J. Exp. Zool. 315, 439-446.

Shimamoto, K., Dewa, Y., Kemmochi, S., Taniai, E., Hayashi, H., Imaoka, M., Shibutani, M., Mitsumori, K., 2011. Relationship between CYP1A induction by indole-3-carbinol or flutamide and liver tumor-promoting potential in rats. Arch. Toxicol. 85, 1159-1166.

Sjöholm, S., 2005. Anti-estrogenicity and anti-androgenicity in leachates from Swedish solid waste deposition sites. In: Dissertation (Master in Biology)-Swedish Environmental Research Institute. Uppsala Universitet, Stockholm, 42p.

Stentiford, G.D., Longshaw, M., Lyons, B.P., Jones, G., Green, M., Feist, S.W. 2003. Histopathological biomarkers in estuarine fish species for the assessment of biological effects of contaminants. Mar. Environ. Res. 55, 137-159.

Stuart, S.N., Chanson, J.S., Cox, N.A., Young, B.E., Rodrigues, A.S.L., Fischman, D.L., Waller, R.W., 2004. Status and trends of amphibian declines and extinctions worldwide. Science 306, 1783-1786.

Terman, A., Brunk, U.T., 2004. Lipofuscin. Int. J. Biochem. Cell Biol. 36, 1400-1404

Tokarz, R.R., 1987. Effects of the antiandrogens cyproterone acetate and flutamide on male reproductive behavior in a lizard (Anolis sagrei). Horm. Behav. 21, $1-16$.

Van Wyk, J.H., Pool, E.J., Leslie, A.J., 2003. The effects of anti-Androgenic and estrogenic disrupting contaminants on breeding gland (Nuptial pad) morphology, plasma testosterone levels, and plasma vitellogenin levels in male Xenopus laevis (African clawed frog). Arch. Eviron. Contam. Toxicol. 44, 247-256.

Vandenberg, L.N., Colborn, T., Hayes, T.B., Heindel, J.J., Jacobs Jr., D.R., Lee, D., Shioda, T., Soto, A.M., vom Saal, F.S., Welshons, W.V., Zoeller, R.T., Myers, J.P., 2012. Hormones and endocrine-disrupting chemicals: low-dose effects and nonmonotonic dose responses. Endocr. Rev. 33 (3), 378-455.

Viguier-Martinez, M.C., Reviers, M.T.H., Barenton, B., Parreau, C., 1983. Effect of a non-steroidal antiandrogen, Flutamide, on the hypothalamo-pituitary axis: genital tract and testis in growing rats: endocrinological and histologcal data. Acta Endocrinol. (Copenh.) 102, 299-306.

Wake, D.B., Vredenburg, V.T., 2008. Are we in the midst of sixth mass extinction? A view from the world of amphibians. Proc. Natl. Acad Sci. 105 (1) 11466-11473.

Welshons, W.V., Thayer, K.A., Judy, B.M., Taylor, J.A., Curran, E.M., vom Saal, F., 2003. Large effects from small exposures. I. Mechanisms for Endocrine-Disrupting-Chemicals with estrogenic activity. Environ. Health Perspect. 111 (8), 994-1006.

Werner, F., 1984. Herpetologische nova. Zool. Anz. 17, 410-415.

Zar, J., 1999. Biostatistical Analyses. Prentice Hall, New Jersey, pp. 663p.

Zuasti, A., Jara, J.R., Ferrer, C., Solano, F., 1989. Occurrence of melanin granules and melanosynthesis in the Kidney of Sparus auratus. Pigment Cell Res. 2, 93-999. 